\title{
Synthesis, Cytotoxicity Assessment, and Molecular Docking of 4-Substituted-2-p-tolylthiazole Derivatives as Probable c-Src and erb Tyrosine Kinase Inhibitors
}

\author{
Alireza Aliabadi, ${ }^{\text {a,b,* }}$ Alireza Foroumadi, ${ }^{\text {b }}$ Maliheh Safavi, ${ }^{c}$ and Sussan K. Ardestanic \\ ${ }^{a}$ Department of Medicinal Chemistry, Faculty of Pharmacy, Kermanshah University of Medical Sciences, \\ Kermanshah, Iran \\ ${ }^{\mathrm{b}}$ Department of Medicinal Chemistry, Faculty of Pharmacy and Pharmaceutical Sciences Research Center, \\ Tehran University of Medical Sciences, Tehran 14174, Iran \\ ${ }^{\mathrm{c}}$ Institute of Biochemistry and Biophysics, Department of Biochemistry, University of Tehran, Tehran, Iran
}

RECEIVED JUNE 3, 2011; REVISED OCTOBER 8, 2012; ACCEPTED MAY 21, 2013

\begin{abstract}
In the current project we focused on the synthesis of 4-Substituted-2-p-tolylthiazole derivatives. Cytotoxicity of synthesized compounds were evaluated against T47D breast cancer cell line and also all of the final compounds 3-7 were docked into the active site of c-Src and erb tyrosine kinases. Compound 4 was the most potent derivative in cytotoxicity assay $\left(\mathrm{IC}_{50}=2.5 \mu \mathrm{g} / \mathrm{mL}\right)$ and it was also the most potent inhibitor of erb tyrosine kinase (Binding free energy: $-10.18 \mathrm{kcal} / \mathrm{mol}$ ).(doi: 10.5562/cca1939)
\end{abstract}

Keywords: synthesis, phenylthiazole, cytotoxicity, breast cancer, tyrosine kinase, docking

\section{INTRODUCTION}

Breast cancer is the leading type of cancer in women and is the second leading cause of cancer death among women. Breast cancer also occurs in men, although far more rarely than in women. ${ }^{1}$

Despite the past efforts to develop selective targeted therapies for the treatment of cancer, the aim has recently turned to find compounds acting on multiple targets in order to face the drug resistance often connected to the activation of alternative signaling pathways. Protein tyrosine kinases occupy a central position in the control of cellular proliferation and their inactivation might lead to the discovery of a new generation anticancer compounds. Multikinase inhibitors currently approved for cancer chemotherapy include lapatinib, sorafenib and dasatinib (Figure 1). These agents are effective in treatment of solid tumors such as breast cancer. $^{2-4}$

c-Src kinase, is the best understood member of a family of related kinases known as the SFKs (Src family kinases). c-Src plays a major role in multiple intracellular signaling pathways involved in cell growth, differentiation, survival, adhesion, and migration. It has been demonstrated that Src is overexpressed or constitutively active in a variety of human tumors like breast cancer.,
The erbB receptors are a family of Type 1 transmembrane receptors that express highly in human tumors. erbB receptors are activated by various growth factor ligands triggering intracellular signalling pathways leading to uncontrolled growth of cancer cells like breast cancer. Lapatinib is an oral 4-anilinoquinazoline derivative that inhibits reversibly tyrosine kinase of HER1, HER2/ErbB2 and EGFR (dual tyrosine kinase inhibitor). ${ }^{7,8}$

In this project we synthesized some new derivatives of 4-Substituted-2-p-tolylthiazole. Docking studies of synthesized compounds into the active site of two types of tyrosine kinases consist of c-Src and erb could suggest the inhibition of these enzymes as probable mechanism for anticancer activity of these compounds in T47D breast cancer cell line.

\section{EXPERIMENTAL}

\section{Chemistry}

All starter materials, reagents and solvents were purchased from diverse commercial companies. The purity of the synthesized compounds was confirmed by thin layer chromatography (TLC) using various solvents of different polarities. Merck silica gel $60 \mathrm{~F}_{254}$ plates were

\footnotetext{
* Author to whom correspondence should be addressed. (E-mail: aliabadi.alireza@gmail.com)
} 
<smiles>CNC(=O)c1cc(Oc2ccc(NC(=O)Nc3ccc(Cl)c(C(F)(F)F)c3)cc2)ccn1</smiles>

Figure 1. Chemical Structures of dasatinib and lapatinib as multikinase inhibitors.

applied for analytical TLC. Column chromatography was performed on Merck silica gel (70-230 mesh) for purification of intermediate and final compounds. ${ }^{1} \mathrm{H}$ NMR spectra were measured using a Varian 400 spectrometer, and chemical shifts are expressed as $\delta$ (ppm) with tetramethylsilane (TMS) as internal standard. The IR spectra were obtained on a Shimadzu 470 spectrophotometer (potassium bromide disks). Melting points were determined on a Kofler hot stage apparatus and are uncorrected. The mass spectra were run on a Finigan TSQ-70 spectrometer (Finigan, USA) at $70 \mathrm{eV}$.
The intended compounds were synthesized according to the Scheme 1.

Synthesis of 4-Methylbenzothioamide (2)

A solution of compound $\mathbf{1}(4 \mathrm{~g}, 35 \mathrm{mmol})$ and ammonium sulfide $20 \%(11.67 \mathrm{ml}, 35 \mathrm{mmol})$ was stirred in 50 $\mathrm{ml}$ of $N, N$-dimethylformamide (DMF) for about $5 \mathrm{~h}$ at room temperature. Cooling the reaction by crushed ice led to the precipitation of compound 2. ${ }^{9}$ Extra purification was done by washing the solid using $n$-hexane. The obtained product was used for the next reaction without any extra purification. m.p. $=160{ }^{\circ} \mathrm{C}$; Yield: $92 \%,{ }^{1} \mathrm{H}$

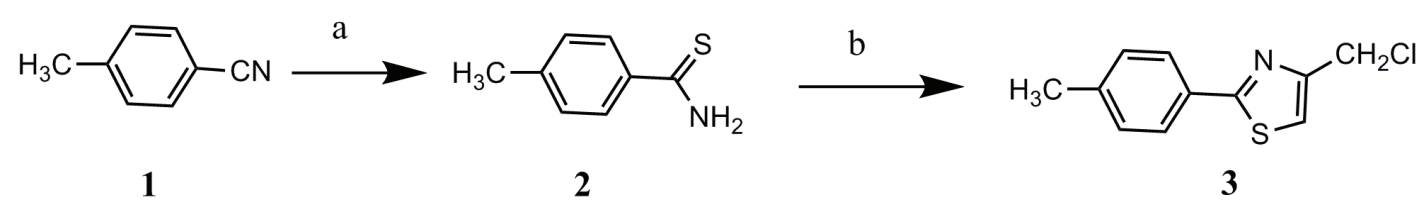

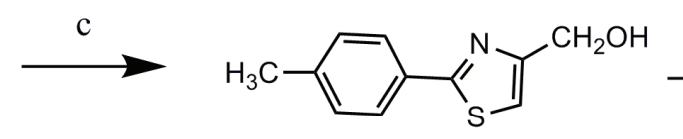

4

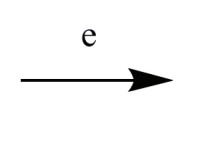

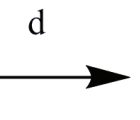<smiles>Cc1ccc(-c2nc(C=O)cs2)cc1</smiles>

5

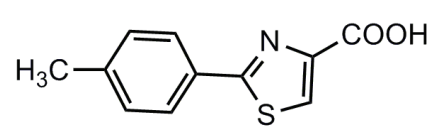

6

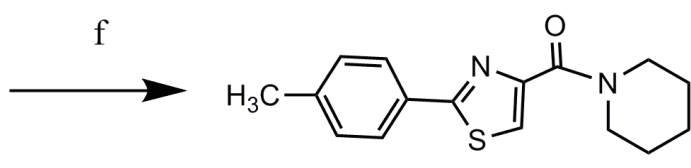

7

Scheme 1. Synthesis of compounds 2-7. a) Ammonium sulfide, DMF, rt, 5 h; b) Toluene, Reflux, 2 h; c) $\mathrm{H}_{2} \mathrm{SO}_{4}, \mathrm{H}_{2} \mathrm{O}, \mathrm{Reflux}_{\text {, }}$ 24-48 h; d) $\mathrm{MnO}_{2}, \mathrm{CHCl}_{3}$, rt, 10 h; e) $\mathrm{H}_{2} \mathrm{O}_{2} 30 \%, \mathrm{KOH}, \mathrm{CH}_{3} \mathrm{OH}$, f) EDC, $\mathrm{HOBt}, \mathrm{CH}_{3} \mathrm{CN}$, piperidine, rt, $24 \mathrm{~h}$. 
NMR (400 MHz, $\left.\mathrm{CDCl}_{3}\right) \delta / \mathrm{ppm}: 2.39\left(\mathrm{~s}, 3 \mathrm{H},-\mathrm{CH}_{3}\right)$, 7.21 (d, 2H, $J=8 \mathrm{~Hz}$, phenyl), 7.79 (d, 2H, $J=8 \mathrm{~Hz}$, phenyl), 7.6 (brs, $\mathrm{NH}_{2}$ ). Elem. anal. for $\mathrm{C}_{8} \mathrm{H}_{9} \mathrm{NS}$ : calcd. C: $63.54, \mathrm{H}: 6.00, \mathrm{~N}: 9.26$; found C: $63.59, \mathrm{H}: 6.17, \mathrm{~N}$ : 9.22 .

Synthesis of 4-(Chloromethyl)-2-p-tolylthiazole (3) A mixture of $2(3.5 \mathrm{~g}, 23 \mathrm{mmol})$ and 1,3-dichloroacetone $(2.9 \mathrm{~g}, 23 \mathrm{mmol})$ were dissolved in $100 \mathrm{ml}$ toluene and the reaction was refluxed for 2 hours. After completion, toluene was evaporated under reduced pressure and water was added. The water layer was extracted three times by $50 \mathrm{ml}$ of ethylacetate. The ethylacetate was washed two times by brine and was dried using dry $\mathrm{NaSO}_{4}$. The ethylacetate was evaporated by rotary evaporator apparatus and afforded precipitate was recrystallization from methanol. ${ }^{10}$ m.p. $=129{ }^{\circ} \mathrm{C}$; Yield: $88 \%$; ${ }^{1} \mathrm{H}$ NMR $\left(400 \mathrm{MHz}, \mathrm{CDCl}_{3}\right) \delta / \mathrm{ppm}: 2.39$ (s, 3H, $\mathrm{CH}_{3}$ ), 4.74 (s, $\left.2 \mathrm{H},-\mathrm{CH}_{2} \mathrm{Cl}\right), 7.25$ (s, $1 \mathrm{H}, \mathrm{C} 4-\mathrm{H}$ thiazole), $7.23\left(\mathrm{~d}, 2 \mathrm{H}, J=8 \mathrm{~Hz}, \mathrm{C}_{3}-\mathrm{H}, \mathrm{C}_{5}-\mathrm{H}\right.$ phenyl), $7.82(\mathrm{~d}, 2 \mathrm{H}$, $J=8 \mathrm{~Hz})$; IR (KBr) $v / \mathrm{cm}^{-1}: 3431,3083(\mathrm{C}-\mathrm{H}$ stretch, aromatic), 2847 (C-H stretch, aliphatic), $1603(\mathrm{C}=\mathrm{C}$ stretch, phenyl), 1460 ( $\mathrm{C}=\mathrm{C}$ stretch, phenyl), 1255, 1152, 999, 809 (C-Cl stretch), 650; MS ( $\mathrm{m} / \mathrm{z}, \%): 223$ (20), 220 (42), 186 (40), 116 (55), 87 (38), 69 (100). Elem. anal. for $\mathrm{C}_{11} \mathrm{H}_{10}$ ClNS: calcd. C: $59.05, \mathrm{H}: 4.51$, $\mathrm{N}: 6.26$; found C: $59.11, \mathrm{H}: 4.49, \mathrm{~N}: 6.31$.

\section{Synthesis of (2-p-tolylthiazol-4-yl)methanol (4)}

The 4-(Chloromethyl)-2-p-tolylthiazole derivative (4.5 g, $22 \mathrm{mmol}$ ) (3) was dissolved in $75 \mathrm{ml}$ water and $75 \mathrm{ml}$ concentrated $\mathrm{H}_{2} \mathrm{SO}_{4}$. The reaction was refluxed for 24 48 hours and the completion was monitored by TLC. The acidic reaction was neutralized by concentrated $\mathrm{NaOH}$ and remain overnight at room temperature to precipitate the product. Purification of the obtained product was done by crystallization from chloroformpetroleum ether. ${ }^{10}$ m.p. $=114-115{ }^{\circ} \mathrm{C}$; Yield: $75 \% ;{ }^{1} \mathrm{H}$ NMR (400 MHz, $\left.\mathrm{CDCl}_{3}\right) \delta /$ ppm: 2.4 (s, $\left.3 \mathrm{H}, \mathrm{CH}_{3}\right), 3.1$ (brs, $1 \mathrm{H}, \mathrm{OH}), 4.8\left(\mathrm{~s}, 2 \mathrm{H}, \mathrm{CH}_{2}\right), 7.2(\mathrm{~d}, 2 \mathrm{H}, J=8 \mathrm{~Hz}$, $\mathrm{C}_{3}-\mathrm{H}, \mathrm{C}_{5}-\mathrm{H}$ phenyl), 7.27 (s, 1H, C4-H thiazole), 7.82 (d, $2 \mathrm{H}, J=8 \mathrm{~Hz}, \mathrm{C}_{2}-\mathrm{H} \mathrm{C}_{6}-\mathrm{H}$ phenyl); IR (KBr) $v / \mathrm{cm}^{-1}$ : 3436, 2929 (C-H stretch, aliphatic), 1649, $1454(\mathrm{C}=\mathrm{C}$ stretch, phenyl), 1152 (C-O, stretch), 1029, 804, 599. Elem. anal. for $\mathrm{C}_{11} \mathrm{H}_{11} \mathrm{NOS}$ : Calc. C: $64.36, \mathrm{H}: 5.40, \mathrm{~N}$ : 6.82; found C: 64.41, H: 5.36, N: 6.85.

Synthesis of 2-p-tolylthiazole-4-carbaldehyde (5) A mixture of (2-p-tolylthiazol-4-yl)methanol derivative (4) $(2.8 \mathrm{~g}, 13 \mathrm{mmol})$ and $\mathrm{MnO}_{2}(9.04 \mathrm{~g}, 104 \mathrm{mmol})$ were added to the $250 \mathrm{ml}$ of chloroform and was stirred at room temperature for 12 hours. Then, chloroform was evaporated under reduced pressure and diethyl ether $\left(\mathrm{Et}_{2} \mathrm{O}\right)$ was added. The mixture was filtered through a packed layer of diatomatous earth and was washed by diethyl ether. Diethyl ether was evaporated under reduced pressure and the product was crystallized from ethanol. ${ }^{10}$ m.p. $=128-130{ }^{\circ} \mathrm{C}$; Yield: $70 \%$; ${ }^{1} \mathrm{H}$ NMR $\left(400 \mathrm{MHz}, \mathrm{CDCl}_{3}\right) \delta / \mathrm{ppm}: 2.4\left(\mathrm{~s}, 3 \mathrm{H}, \mathrm{CH}_{3}\right), 7.25(\mathrm{~d}$, $2 \mathrm{H}, J=8 \mathrm{~Hz}, \mathrm{C}_{3}-\mathrm{H}, \mathrm{C}_{5}-\mathrm{H}$ phenyl), $7.84(\mathrm{~d}, 2 \mathrm{H}, J=8 \mathrm{~Hz}$, $\mathrm{C}_{2}-\mathrm{H} \mathrm{C}_{6}-\mathrm{H}$ phenyl), 8.1 (s, 1H, C4-H thiazole), 10.1 (s, C-H aldehyde); MS (m/z, \%): 204 (15), 201 (100), 173 (30), 140 (58), 115 (68), 89 (40), 84 (65), 58 (85). Elem. anal. for $\mathrm{C}_{11} \mathrm{H}_{9} \mathrm{NOS}$ : calcd. C: $65.00, \mathrm{H}: 4.46, \mathrm{~N}: 6.89$; found C: 64.93, H: 5.53, N: 6.83 .

\section{Synthesis of 2-p-tolylthiazole-4-carboxylic acid (6)}

Hydrogen peroxide $30 \%(4 \mathrm{ml}, 40 \mathrm{mmol})$ was added dropwise to the 2-p-tolylthiazole-4-carbaldehyde (5) $(1 \mathrm{~g}, 5 \mathrm{mmol})$ and $50 \%$ aqueous $\mathrm{KOH}(1.47 \mathrm{ml}, 20$ mmol) in methanol under reflux condition $\left(65^{\circ} \mathrm{C}\right)$ for about 20 minutes and reflux conditions was continued for 10 minutes. The mixture was cooled and acidified with concentrated hydrochloric acid. ${ }^{11}$ m.p. $=123{ }^{\circ} \mathrm{C}$; Yield: $82 \%$; ${ }^{1} \mathrm{H}$ NMR $\left(400 \mathrm{MHz}, \mathrm{CDCl}_{3}\right.$ ) $\delta / \mathrm{ppm}: 2.4$ (s, $\left.3 \mathrm{H}, \mathrm{CH}_{3}\right), 7.25$ (d, $2 \mathrm{H}, J=8 \mathrm{~Hz}, \mathrm{C}_{3}-\mathrm{H}, \mathrm{C}_{5}-\mathrm{H}$ phenyl), $7.9\left(\mathrm{~d}, 2 \mathrm{H}, J=8 \mathrm{~Hz}, \mathrm{C}_{2}-\mathrm{H}, \mathrm{C}_{6}-\mathrm{H}\right.$ phenyl), $8.14(\mathrm{~s}, 1 \mathrm{H}$, $\mathrm{C} 4-\mathrm{H}$ thiazole). IR (KBr) $v / \mathrm{cm}^{-1}: 3277(\mathrm{OH}$ stretch), 3078 (C-H stretch, aromatic), 2919 (C-H stretch, aliphatic), 2858 (C-H stretch, aliphatic), $1721 \quad(\mathrm{C}=\mathrm{O}$ stretch), $1603(\mathrm{C}=\mathrm{C}$ stretch, phenyl), 1521, $1454(\mathrm{C}=\mathrm{C}$ stretch, phenyl), 1403, 1342, 1244 (C-O stretch), 809; MS (m/z, \%): 221 (10), 219 (100), 175 (22), 134 (30), 119 (95), 115 (75), 91 (40), 56 (32). Elem. anal. for $\mathrm{C}_{11} \mathrm{H}_{9} \mathrm{NO}_{2} \mathrm{~S}$ : calcd. C: $60.26, \mathrm{H}: 4.14, \mathrm{~N}: 6.39$; found $\mathrm{C}$ : 60.21, H: 4.17, N: 6.44.

Synthesis of Piperidin-1-yl(2-p-tolylthiazol-4-yl)methanone (7)

Carboxylic acid derivative 6 ( $1 \mathrm{~g}, 4 \mathrm{mmol})$, EDC (0.8 $\mathrm{g}, 4 \mathrm{mmol})$ and hydroxybenzotriazole (HOBt) $(0.5 \mathrm{~g}, 4$ $\mathrm{mmol})$ were stirred in acetonitrile at room temperature for 30 minutes. Then, piperidine $(0.38 \mathrm{~g}, 0.45 \mathrm{ml}, 16$ $\mathrm{mmol}$ ) was added to the reaction mixture and stirring was continued for $24 \mathrm{~h}$. Acetonitrile was evaporated under reduced pressure and ethyl acetate was added to the residue. Ethyl acetate was washed with diluted sulfuric acid $\left(\mathrm{H}_{2} \mathrm{SO}_{4}\right)$, sodium bicarbonate $\left(\mathrm{NaHCO}_{3}\right)$ and brine. Ethyl acetate phase was separated and anhydrous sodium sulfate $\left(\mathrm{Na}_{2} \mathrm{SO}_{4}\right)$ was added for drying. Evaporation of ethyl acetate yielded the related amide derivative 7. Diethyl ether was added for washing the product and the solid was filtered. m.p. $=78$ ${ }^{\circ} \mathrm{C}$; Yield: $70 \%$; ${ }^{1} \mathrm{H}$ NMR $\left(400 \mathrm{MHz}, \mathrm{CDCl}_{3}\right) \delta / \mathrm{ppm}$ : $1.7\left(\mathrm{~m}, 2 \mathrm{H},-\mathrm{CH}_{2^{-}}\right.$piperidine $), 2.37\left(\mathrm{~m},-\mathrm{CH}_{2}-\right.$, piperidine), $2.4\left(\mathrm{~s}, 3 \mathrm{H},-\mathrm{CH}_{3}\right), 3.77\left(\mathrm{~m},-\mathrm{N}^{-} \mathrm{CH}_{2}-\right.$, piperidine), 7.22 (d, $2 \mathrm{H}, J=8 \mathrm{~Hz}, \mathrm{C}_{3}-\mathrm{H}, \mathrm{C}_{5}-\mathrm{H}$ phenyl), 7.78 (s, $1 \mathrm{H}, \mathrm{C}-\mathrm{H}$ thiazole), $7.84\left(\mathrm{~d}, 2 \mathrm{H}, J=8 \mathrm{~Hz}, \mathrm{C}_{2}-\right.$ $\mathrm{H}, \mathrm{C}_{6}-\mathrm{H}$ phenyl); MS (m/z, \%): 287 (5), 286 (15), 265 (20), 202 (65), 174 (20), 149 (25), 116 (40), 91 (82), 89 (100), 85 (40), 54 (22). Elem. anal. for $\mathrm{C}_{16} \mathrm{H}_{18} \mathrm{~N}_{2} \mathrm{OS}$ : Calc. C: 67.10, H: 6.33, N: 9.78; found C: 66.97, H: 6.28, N: 9.83 . 
Table 1. Cytotoxicity results $\left(\mathrm{IC}_{50}, \mu \mathrm{g} / \mathrm{mL}\right)$ and binding free energy $(\mathrm{Kcal} / \mathrm{mol})$ of ligands after docking study

\begin{tabular}{|c|c|c|c|c|}
\hline & $\mathrm{R}$ & $\begin{array}{l}\mathrm{IC}_{50}(\mathrm{~T} 47 \mathrm{D}) \\
(\mu \mathrm{g} / \mathrm{mL})\end{array}$ & $\begin{array}{c}\text { Binding free energy }(\mathrm{kcal} / \mathrm{mol}) \\
\mathrm{c} \text {-Src tyrosine kinase }\end{array}$ & $\begin{array}{c}\text { Binding free energy }(\mathrm{kcal} / \mathrm{mol}) \\
\text { erb tyrosine kinase }\end{array}$ \\
\hline 3 & $-\mathrm{CH}_{2} \mathrm{Cl}$ & 5 & -9.13 & -9.83 \\
\hline 4 & $-\mathrm{CH}_{2} \mathrm{OH}$ & 2.5 & -9.34 & -10.18 \\
\hline 5 & $-\mathrm{CHO}$ & $>10$ & -9.02 & -9.01 \\
\hline 6 & $-\mathrm{COOH}$ & $>10$ & -9.08 & -9.85 \\
\hline \multirow[t]{2}{*}{7} & -CO-piperidine & 5 & -9.57 & -9.79 \\
\hline & Doxorubicin & 2.5 & - & - \\
\hline
\end{tabular}

\section{Docking Studies}

Docking studies were done using ArgusLab 4.0 software. ${ }^{12}$ All ligands were drawn and energy minimization was performed for all of them by AM1 semiemperical method. The related pdb files of c-Src and erb protein tyrosine kinases were downloaded from protein databank with $3 \mathrm{G} 5 \mathrm{D}$ and $3 \mathrm{BBT}$ pdb code respectively. ${ }^{13}$ The geometry optimization of protein structures were performed using UFF molecular mechanic force field. The docking process was done for all ligands in the workspace of ArgusLab software after defining the related groups for each ligand and also for protein. The binding location of lapatinib and dasatinib in the crystal structure of each tyrosine kinase enzyme was assumed as the reference binding location for finding the best pose and conformation for all ligands. The grid box for docking of each ligand was considered and its size was calculated by ArgusLab software automatically. A grid resolution $0.4 \AA$ was assigned and maximum number of poses was defined 150 poses. Ascore was used as scoring function in this process. ArgusDock was applied as docking engine. Docking process run according to the flexible ligand docking for all intended ligands and regular precision was applied for docking precision. Binding free energies were acquired and listed in Table 1. Binding mode and related interactions of ligands were explored in Molegro molecular viewer software. ${ }^{14}$

\section{Cytotoxicity Assay}

Compounds 3-7 were tested against T47D cells as breast cancer cell line according to the literature. ${ }^{15}$ The MTT assay were used for obtaining $\mathrm{IC}_{50}(\mu \mathrm{g} / \mathrm{mL})$ in the presence of doxorubicin as reference drug.

\section{RESULTS AND DISCUSSION}

\section{Chemistry}

All compounds were synthesized according to the Scheme 1 with acceptable yields (Table 2). $p$ toluonitrile was used to commence the synthesis process. The conversion of nitrile group to thioamide derivative was done using ammonium disulfide. Thiazole ring closure was carried out by dichloroacetone and acid hydrolysis of obtained chloromethyl derivative led to the related alcohol derivative. Two continuous oxidative reactions were afforded the carboxylic derivative by passing from an aldehyde intermediate. Intermediate and final compounds were purified by crystallization or column chromatography and were characterized by NMR, IR and Mass spectroscopy and also elemental analysis was reported for all synthesized compound.

\section{Cytotoxicity Assay}

MTT assay was done for compounds 3-7 and the results of cytotoxicity assay were listed as $\mathrm{IC}_{50}(\mu \mathrm{g} / \mathrm{mL})$ in

Table 2. The properties related to the compounds 2-7

\begin{tabular}{llccc}
\hline & Closed Formula & Molecular Weight $(\mathrm{g} / \mathrm{mol})$ & Yield $/ \%$ & Melting point $/{ }^{\circ} \mathrm{C}$ \\
\hline $\mathbf{2}$ & $\mathrm{C}_{8} \mathrm{H}_{9} \mathrm{NS}$ & 151 & 92 & 160 \\
$\mathbf{3}$ & $\mathrm{C}_{11} \mathrm{H}_{10} \mathrm{ClNS}$ & 223 & 88 & 129 \\
$\mathbf{4}$ & $\mathrm{C}_{11} \mathrm{H}_{11} \mathrm{NOS}$ & 205 & 75 & $114-115$ \\
$\mathbf{5}$ & $\mathrm{C}_{11} \mathrm{H}_{9} \mathrm{NOS}$ & 203 & 70 & $128-130$ \\
$\mathbf{6}$ & $\mathrm{C}_{11} \mathrm{H}_{9} \mathrm{NO}_{2} \mathrm{~S}$ & 219 & 82 & 123 \\
$\mathbf{7}$ & $\mathrm{C}_{16} \mathrm{H}_{18} \mathrm{~N}_{2} \mathrm{OS}$ & 286 & 70 & 78 \\
\hline
\end{tabular}




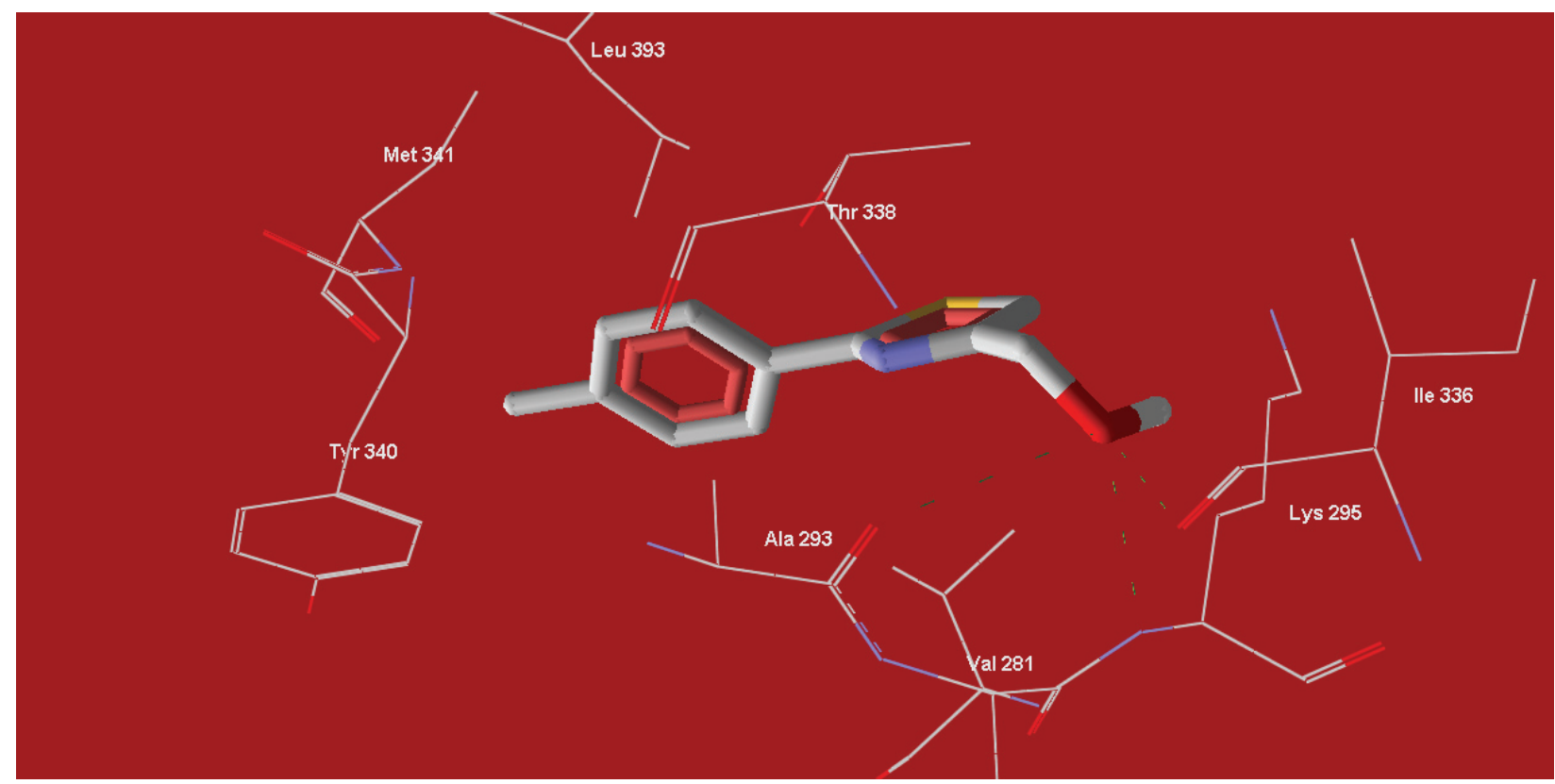

Figure 2. 3D view of compound 4 after molecular docking into the active site of c-Src tyrosine kinase (PDB code: 3G5D). Ligand is rendered in stick and amino acid residues of protein in frame. Three hydrogen bindings between hydroxyl residue of compound 4 and Ileu 336 (2.34 $\AA$ ), Lys 295 (2.76 $\AA$ ) and Ala 293 (3.60 $\AA)$ are visible and have been represented in green dashed.

Table 1. The potencies of all compound were compared with doxorubicin in T47D cell line. Compound 4 with hydroxymethyl moiety was the best in this series with equal $\mathrm{IC}_{50}$ in comparison with doxorubicin. Compound $\mathbf{5}$ and 6 showed lower potency than reference drug with formyl and carboxylate substitutions respectively. Chloro- methyl substitution in compound $\mathbf{3}$ as well as piperidinylcarbonyl substitution in compound 7 afforded two compounds with lower potency than doxorubicin. Although compounds 3 and 7 were weaker than reference drug, but both of them have acceptable inhibitory concentration in this series and also in comparison with doxorubicin.

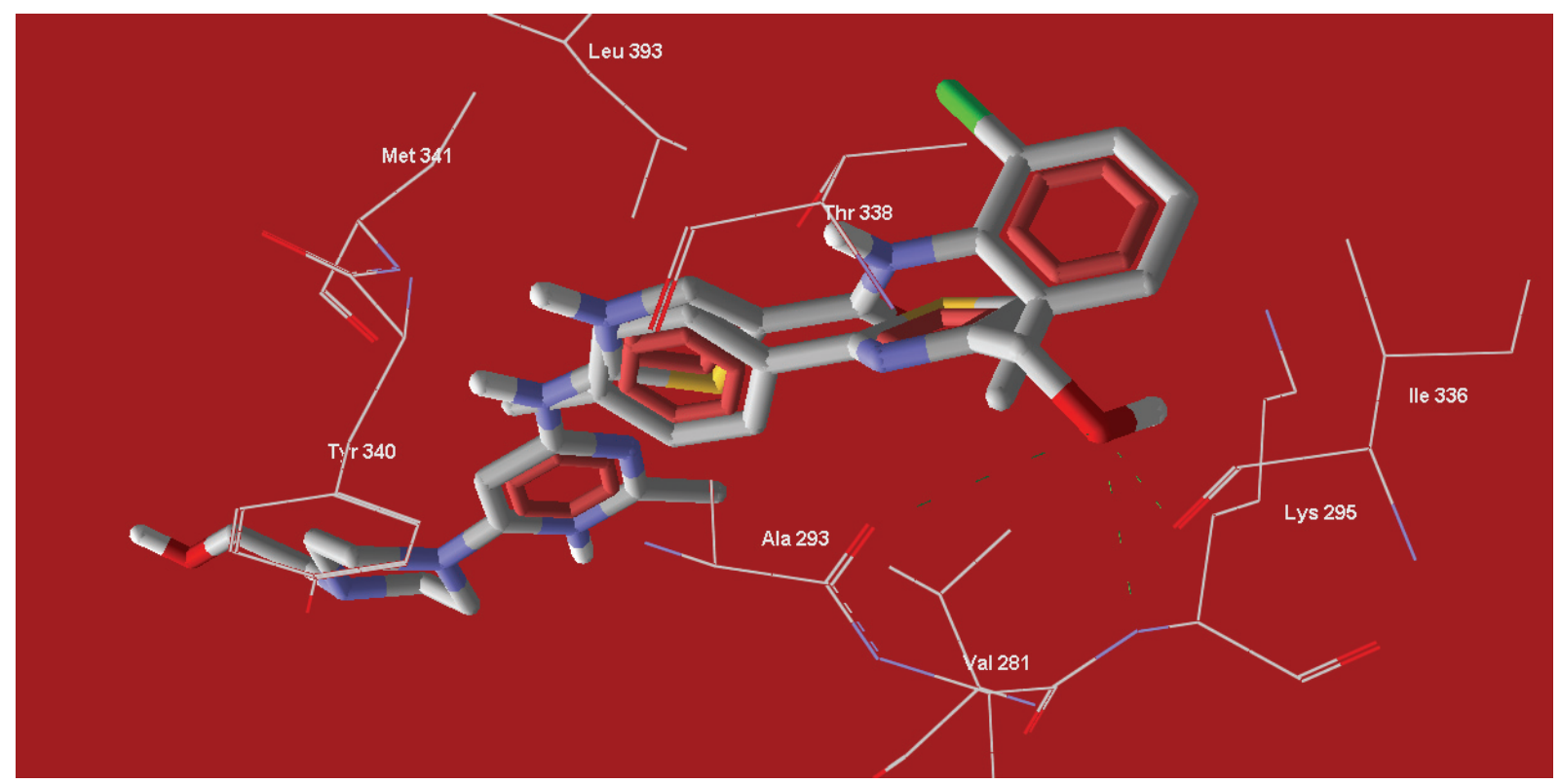

Figure 3. 3D view of superimposed structure of compound 4 with dasatinib. A good overlaid of phenyl ring of the compound 4 with thiazole ring of the dasatinib is observed. 


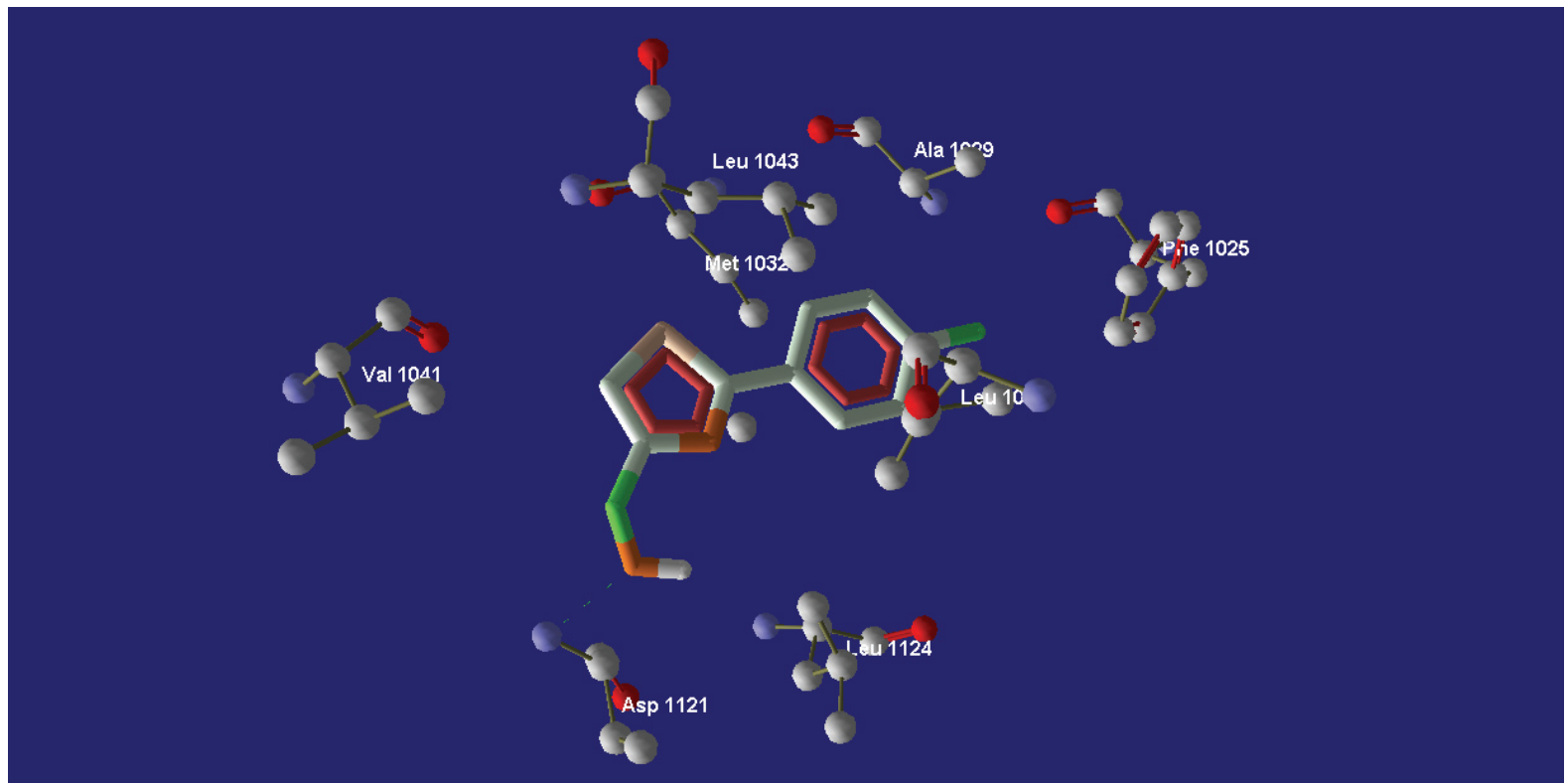

Figure 4. 3D view of compound 4 after molecular docking into the active site of erb tyrosine kinase (PDB code: 3BBT). Ligand is rendered in stick and amino acid residues of protein in ball-stick. Hydrogen binding between hydroxyl residue of compound $\mathbf{4}$ and Asp 1121 is visible and has been represented in green dashed. The hydrogen binding distance between the hydroxyl group and Asp amino acid is $2.41 \AA$.

\section{Molecular Docking}

All ligands (compound 3-7) were docked into the active site of c-Src tyrosine kinase as well as erb tyrosine kinase for obtaining the likely interactions. This two types of tyrosine kinases have pivotal role in pathology of breast cancer. Docking studies of ligands were revealed the probable interactions between the ligands and both of cSrc and erb tyrosine kinases. Molecular docking of compound 7 with piperidinylcarbonyl moiety into the active site of c-Src tyrosine kinase showed the highest binding free energy in comparison with other agents in the series. Compound $\mathbf{5}$ with a formyl group was the weakest agent for inhibition of c-Src tyrosine kinase. Compound $\mathbf{4}$ with hydroxymethyl substitution was obtained the second rank of calculated enzyme inhibition and a hydrogen binding interaction was showed in the most stable conformation

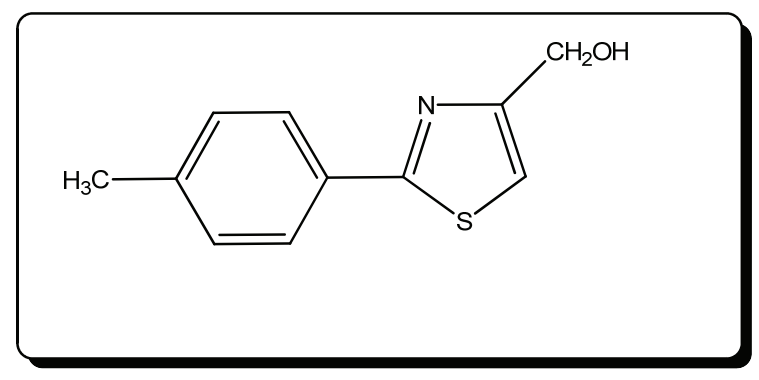

Figure 5. Structure of compound 4 with hydroxyl substituent as potential anticancer lead compound (IC50 $=2.5 \mu \mathrm{g} / \mathrm{mL}$ ). of this ligand in the active site of c-Src tyrosine kinase. Three hydrogen bindings between hydroxyl residue of compound 4 and Ileu 336 (2.34 $\AA$ ), Lys 295 (2.76 $\AA$ ) and Ala 293 (3.60 $\AA$ ) were detected (Figure 2). A superimposed conformation of compound $\mathbf{4}$ with dasatinib was also prepared (Figure 3). According to this figure, the phenyl ring of compound $\mathbf{4}$ occupied a similar location in the active site of Src kinase like thiazole ring of dasatinib.

According to the Table 1, molecular docking of ligands 3-7 into the active site of erb tyrosine kinase showed the highest binding free energy for compound 4 $(-10.18 \mathrm{Kcal} / \mathrm{mol})$ and a very important hydrogen binding were detected between the hydroxyl moiety of compound $\mathbf{4}$ and Asp 1121 in the active site of erb tyrosine kinase (Figure 4).

\section{CONCLUSION}

A new series of phenylthiazole analogs were synthesized and their anticancer activity was evaluated in vitro. According to the obtained data from molecular modeling and cytotoxicity evaluation, it could be concluded that 4-Substituted-2- $p$-tolylthiazole derivatives have acceptable in silico inhibition of c-Src and erb tyrosine kinases in neoplastic cells. Cytotoxicity assessment against T47D breast cancer cell line approved the in vitro efficacy of these compounds. Compound 4 with an alcoholic (Hydroxymethyl) moiety was the best compound in this series (IC50 $=2.5$ 
$\mu \mathrm{g} / \mathrm{mL})$. Hydrogen binding interactions of compound 4 via hydroxyl substituent enhances its activity compared to other synthesized derivatives in this series. Finally, we conclude that compound $\mathbf{4}$ can be proposed as potential anticancer lead compound (Figure 5). But, further experimental tests are necessary to prove this statement.

Acknowledgements. This work was supported by a grant from the Research Council of Kermanshah University of Medical Sciences.

\section{REFERENCES}

1. K. Rakash and W. Rui-an, Micros. Res. Tech. 59 (2002) 49-57.

2. C. Emmanuele, R. Marco, S. Zanoli, S. Schenone, M. Botta, and G. Maga, Bioorg. Med. Chem. 18 (2010) 3999-4008.

3. H. Bhuva and S. G. Kini, J. Mol. Graph. Model. 29 (2010) 32-37.

4. S. Olgen, E. Akaho, and D. Nebioglu, J. Enzyme Inhib. Med. Chem. 18 (2003) 485-490.
5. K. Lee, J. Kim, K.-W. Jeong, K. W. Lee, Y. Lee, J. Y. Song, M. S. Kim, G. S. Lee, and Y. Kim, Bioorg. Med. Chem. 17 (2009) 3152-3161.

6. N. Atatreh, J. Barraclough, A. Welman, C. Cawthorne, R. A Bryce, C. Dive, and S. Freeman, J. Enzyme Inhib. Med. Chem. 22 (2007) 638-646.

7. D. Bilancia, G. Rosati, A. Dinota, D. Germano, R. Romano, and L. Manzione, Ann. Oncol. 18 (2007) 26-30.

8. A. Agrawal, E. Gutteridge, J. M. W. Gee, R. I. Nicholson, and J. F. R Robertson, Endocr. Relat. Cancer 12 (2005) 135-144.

9. D. Sally and J. W. Richard, Tetrahedron Lett. 47 (2006) 8147-8150.

10. M. Mahmoodi, A. Aliabadi, S. Emami, M. Safavi, S. Rajabalian, M. A. Mohagheghi, A. Khoshzaban, A. Samzadeh-Kermani, N. Lamei, A. Shafiee, and A. Foroumadi, Arch. Pharm. Chem. 343 (2010) 411-416.

11. C. Zhi-Qi, W. Chun-Ian, C. Tie, and Y. Bing-Zhu. Synth. Commun. 36 (2006) 679-683.

12. ArgusLab 4.0 Mark A. Thompson Planaria Software LLC, Seattle, WA. http://www.arguslab.com.

13. http://RCSB.org.

14. http://www.molegro.com

15. A. Aliabadi, F. Shamsa, S. N. Ostad, S. Emami, A. Shafiee, J. Davoodi, and A. Foroumadi, Eur. J. Med. Chem. 45 (2010) 5384-5389. 